\title{
EGFR amplification and expression in oral squamous cell carcinoma in young adults ts
}

V. Costa, L. P. Kowalski, C. M. Coutinho-Camillo, M. D. Begnami, V. F. Calsavara, J. I. Neves, E. Kaminagakura: EGFR amplification and expression in oral squamous cell carcinoma in young adults. Int. J. Oral Maxillofac. Surg. 2018; 47: 817-823. (C) 2018 International Association of Oral and Maxillofacial Surgeons. Published by Elsevier Ltd. All rights reserved.

Abstract. The aim of this study was to investigate epidermal growth factor receptor (EGFR) gene alterations in two groups of patients with oral squamous cell carcinoma (OSCC) (a test group of subjects aged $\leq 40$ years and a control group of subjects aged $\geq 50$ years) and to associate the results with EGFR immunostaining, clinicopathological features, and the prognosis. Sixty cases of OSCC were selected (test group, $n=21$; control group, $n=39$ ). The tissue microarray technique was applied to ensure the uniformity of results. Gene amplification was analyzed by fluorescence in situ hybridization (FISH), and immunohistochemical staining for EGFR was analyzed using an automated imaging system. EGFR amplification was higher in the test group than in the control group $(P=0.018)$ and was associated with advanced clinical stage $(P=0.013)$, regardless of age. Patients with EGFR overexpression had worse survival rates, as did patients who had T3-T4 tumours and positive margins. EGFR overexpression has a negative impact on disease progression. Despite the higher amplification of EGFR in young adults, it does not significantly impact the survival rates of affected patients.

Key words: oral cancer; squamous cell carcinoma; EGFR gene; fluorescence in situ hybridization; immunohistochemistry; prognosis.

Accepted for publication 3 January 2018 Available online 1 February 2018
Oral squamous cell carcinoma (OSCC) is a malignant epithelial neoplasm that mainly affects alcohol- and tobacco-using patients in the fifth and sixth decades of life ${ }^{1}$. Rising trends of oral cancer have been reported among young and middleaged individuals under the age of 45

\footnotetext{
th All authors reviewed and approved the final paper prior to its submission.
}

years $^{2}$, women, and patients who have never been exposed to aetiological factors $^{3-5}$. In this respect, cancer pathogenesis and genetic alterations have been studied to determine the probable causes of cancer in young adults $(\leq 40$ years of age) ${ }^{6,7}$.

The epidermal growth factor receptor (EGFR) plays an important role in the growth and progression of solid tumours ${ }^{8}$.

\author{
V. Costa ${ }^{1}$, L. P. Kowalski ${ }^{2}$, \\ C. M. Coutinho-Camillo ${ }^{3,4}$, \\ M. D. Begnami ${ }^{4}$, V. F. Calsavara ${ }^{5}$, \\ J. I. Neves ${ }^{4}$, E. Kaminagakura ${ }^{1}$ \\ ${ }^{1}$ Department of Biosciences and Oral \\ Diagnosis, Institute of Science and \\ Technology, São Paulo State University \\ (Unesp), São José dos Campos, Brazil; \\ 2Department of Head and Neck Surgery and \\ Otorhinolaryngology, A.C. Camargo Cancer \\ Center, São Paulo, Brazil; ${ }^{3}$ International \\ Research Center, A.C. Camargo Cancer \\ Center, São Paulo, Brazil; ${ }^{4}$ Department of \\ Anatomic Pathology, A.C. Camargo Cancer \\ Center, São Paulo, Brazil; ${ }^{5}$ Department of \\ Epidemiology and Statistics, A.C. Camargo \\ Cancer Center, São Paulo, Brazil
}

EGFR is a tyrosine kinase receptor and a member of the ErbB receptor family, which includes EGFR/erbB-1, HER2/ erbB-2, HER3/erbB-3, and HER4/erbB4. This receptor contains an external ligand-binding domain, a transmembrane domain, and a cytoplasmic domain, and is considered a potential therapeutic target in carcinomas ${ }^{8-12}$. Amplification of the EGFR gene $(E G F R)$ is observed in ap- 
proximately $15.4 \%$ to $31.2 \%$ of OSCC cases $^{13,14}$.

Radiation combined with EGFR inhibitors has been used successfully for the local treatment of advanced head and neck tumours $^{15}$. However, in view of the high cost of anti-EGFR therapy ${ }^{16}$, it is necessary to identify the group that will best respond to this therapy, as suggested by Galvis et al. ${ }^{17}$. The aim of this study was to investigate $E G F R$ alterations in two groups of patients with OSCC (a test group of subjects aged $\leq 40$ years and a control group of subjects aged $\geq 50$ years) and to associate the results with EGFR immunostaining, clinicopathological features, and the prognosis.

\section{Materials and methods}

A retrospective study was performed involving 60 patients (test group, $n=21$; control group, $n=39$ ) with OSCC treated from 1970 to 2007 at the Department of Head and Neck Surgery and Otorhinolaryngology of the A.C. Camargo Cancer Center, São Paulo, Brazil. Demographic characteristics (age, sex, and race), lifestyle habits (smoking habit and alcohol consumption), clinical variables (tumour site and clinical stage), treatment, pathological factors (histological grade), and follow-up (minimum of 60 months) were analyzed. The Ethics Committee of the Institute of Science and Technology, Unesp approved the study.

The clinical characteristics of the patients were obtained from their medical records and the tumours were staged according to the American Joint Committee on Cancer (AJCC) Cancer Staging Manual $^{18}$. The histopathological diagnoses were reviewed and the histological grade was determined based on the classification proposed by the World Health Organization for head and neck tumours ${ }^{1}$. Two previously calibrated examiners independently performed this analysis. The kappa test was used to determine agreement between the examiners (VC, EK). In the case of any discrepancy, a third observer was consulted (MDB).

The tissue microarray (TMA) blocks were constructed as described by Kaminagakura et al. $(2010)^{19}$.

\section{Dual-colour fluorescence in situ hybridization (FISH)}

One slide from each TMA block was subjected to hybridization. A ZytoLight SPEC EGFR/CEN7 Dual Color Probe (ZytoVision GmbH, Bremerhaven, Germany), which contains both the fluo- rescently labelled EGFR gene and chromosome 7 centromere probes, was used for FISH. Briefly, the sections were incubated at $56{ }^{\circ} \mathrm{C}$ overnight and deparaffinized by washing in xylene, ethanol, and distilled water. After incubation in $0.2 \mathrm{M} \mathrm{HCl}$ for $20 \mathrm{~min}$ at room temperature, the sections were heat pre-treated in saline-sodium citrate buffer $(2 \times \mathrm{SSC}, \mathrm{pH}$ 6.0) for $1 \mathrm{~h}$ at $80^{\circ} \mathrm{C}$. Next, the sections were digested with pepsin for $8 \mathrm{~min}$ at room temperature, rinsed in $2 \times \mathrm{SSC}$ for $2 \mathrm{~min}$ at room temperature, and dehydrated in an increasing ethanol series $(75 \%, 80 \%$, and $100 \%)$ for 2 min each. The EGFR/CEN7 probe mix was applied to dry slides and the tissue area was coverslipped and sealed with rubber cement. The slides were then incubated in a hybridizer (S2450; Dako, Glostrup, Denmark) for denaturation at $75^{\circ} \mathrm{C}$ for $10 \mathrm{~min}$ and hybridization at $37^{\circ} \mathrm{C}$ for approximately $18 \mathrm{~h}$. Post-hybridization washes were performed in urea/ $0.1 \times$ $\mathrm{SSC}$ for $30 \mathrm{~min}$ at $45^{\circ} \mathrm{C}$ and in $2 \times \mathrm{SSC}$ for $2 \mathrm{~min}$ at room temperature. The slides were dehydrated in serial ethanol solutions, following which $15 \mu \mathrm{l}$ of mounting medium containing $4^{\prime}, 6^{\prime}$-diamidino-2phenylindole (DAPI) was applied, and the tissue area was coverslipped.

The criteria proposed by Jiang et al. were used to establish whether the FISH results were evaluable ${ }^{20}$. In each case, 30 non-overlapping, intact interphase tumour nuclei identified by DAPI staining were evaluated and the copy numbers of $E G F R$ (green signal) and CEN7 (red signal) in each nucleus were determined. Amplification was defined when the average copy number ratio, $E G F R / C E N 7$, was $\geq 2.0$ in all nuclei evaluated, or when the EGFR signals formed a tight gene cluster.

\section{Immunohistochemistry}

The TMA sections were preheated for $24 \mathrm{~h}$ at $60{ }^{\circ} \mathrm{C}$, deparaffinized, and rehydrated in serial ethanol solutions. Antigen retrieval was performed in a pressure cooker in $10 \mathrm{mM}$ citric acid solution (pH 6.0). Endogenous peroxidase activity was blocked with $6 \%$ hydrogen peroxide, followed by a washing step in $10 \mathrm{mM}$ Tris-buffered saline ( $\mathrm{pH}$ 7.4) for $5 \mathrm{~min}$. Next, the sections were incubated with ready-for-use primary antibodies against EGFR protein (1:500, clone NB100-595; Novus Biologicals, Littleton, CO, USA) at $4{ }^{\circ} \mathrm{C}$ overnight. After this period, the sections were washed in Tris-buffered saline and incubated with biotin-free horseradish peroxidase (HRP-EnVision; DakoCytomation, Carpinteria, CA, USA) for
$30 \mathrm{~min}$. The reaction was developed using diaminobenzidine (DakoCytomation) as chromogen. The sections were counterstained with Mayer's haematoxylin, dehydrated, and mounted. Positive and negative controls were included in all reactions.

An automated imaging system (ACIS III; Dako, Carpinteria, CA, USA) was used for quantitative analysis. This system detects levels of hue, saturation, and luminosity, converting the signals into a numerical measure of density (staining intensity) ranging from 60 to 256 . The analysis was performed according to the criteria proposed by Fukazawa et al. ${ }^{21}$. To analyze immunohistochemical EGFR expression, the membrane histo program was used to measure optical membrane density. The operator quantified at least five areas showing the highest staining intensity, as recommended by the manufacturer of the equipment (ACIS III; Dako). The selected areas were restricted to OSCC cells.

\section{Statistical analysis}

The baseline patient characteristics are expressed as absolute and relative frequencies for qualitative variables and as the median, minimum and maximum for quantitative variables. The association between qualitative variables was evaluated by $\chi^{2}$ test or Fisher's exact test, as appropriate. The non-parametric Mann-Whitney $U$-test was applied to compare the variable age between the groups (test and control).

Regarding the expression of EGFR, the determination of two groups of observations with respect to a simple cut-off point was estimated using the maximum of the standardized log-rank statistic proposed by Lausen and Schumacher ${ }^{22}$. In each analysis, the maximally selected log-rank statistic for cut-off points between $5 \%$ and $95 \%$ of continuous measure was considered. The Kaplan-Meier estimator of the survival function was considered for survival analysis and the log-rank test was used to compare the survival distribution between groups. The Cox semiparametric proportional hazards model was used to describe the relationship between survival and relapse times and the covariate defined with respect to a cut-off point ${ }^{23}$. The assumption of proportional hazards was assessed based on the so-called Schoenfeld residuals ${ }^{24,25}$. There was evidence that covariates had a constant effect over time in all cases.

Overall survival was calculated from the date of primary treatment to death. 
Disease-free survival was calculated from the date of primary treatment to the date of first recurrence. Disease-specific survival was calculated from the date of primary treatment to death from OSCC.

The significance level was fixed at $5 \%$ for all tests. Statistical analyses were performed using IBM SPSS Statistics version 23.0 (IBM Corp., Armonk, NY, USA) and $\mathrm{R}$ software version 3.4 (R Foundation for Statistical Computing, Vienna, Austria).

\section{Results}

The clinicopathological data of the participants are summarized in Table 1 . Twenty-one samples from the test group $(\leq 40$ years old) and 39 samples from the control group ( $\geq 50$ years old) were suitable for evaluation. Regardless of age, univariate and multivariate Cox proportional hazards regression models were performed, related to clinicopathological variables (Table 2). In the multivariate analysis, patients who presented T3/T4 tumours and those who had positive margins were at a significantly increased risk of death from disease (hazard ratio 6.52 and 5.94, respectively; both $P<0.05$ ).

Gene amplification was found in six cases $(28.6 \%)$ in the test group and in two cases $(5.1 \%)$ in the control group (Fig. 1). Significantly higher gene amplification $(P=0.018)$ was observed in the test group (Table 3). Membrane overexpression of EGFR was observed in $66.7 \%$ of the test group and in $53.8 \%$ of the control group (Fig. 1), with no significant

Table 1. Demographic and clinical characteristics.

\begin{tabular}{|c|c|c|c|}
\hline Characteristics & Test group $(n=21)$ & Control group $(n=39)$ & $P$-value \\
\hline \multicolumn{4}{|l|}{ Age, years } \\
\hline Mean & 35.0 & 60.0 & \multirow[t]{2}{*}{$<0.001$} \\
\hline Range & $20-40$ & $51-80$ & \\
\hline \multicolumn{3}{|l|}{ Sex, $n(\%)$} & \multirow[t]{3}{*}{0.582} \\
\hline Male & $14(67 \%)$ & $30(77 \%)$ & \\
\hline Female & $7(33 \%)$ & $9(23 \%)$ & \\
\hline \multicolumn{3}{|l|}{ Race, $n(\%)$} & \multirow[t]{3}{*}{0.493} \\
\hline White & $16(76 \%)$ & $33(85 \%)$ & \\
\hline Other & $5(24 \%)$ & $6(15 \%)$ & \\
\hline \multicolumn{3}{|l|}{ Location, $n(\%)$} & \multirow[t]{6}{*}{$0.807^{\mathrm{a}}$} \\
\hline Tongue & $11(52 \%)$ & $22(56 \%)$ & \\
\hline Floor of the mouth & $4(19 \%)$ & $5(13 \%)$ & \\
\hline Retromolar area & $2(10 \%)$ & $7(18 \%)$ & \\
\hline Buccal mucosa & $1(5 \%)$ & $1(3 \%)$ & \\
\hline Not reported & $3(14 \%)$ & $4(10 \%)$ & \\
\hline \multicolumn{3}{|l|}{ Tobacco use, $n(\%)$} & \multirow[t]{3}{*}{1.000} \\
\hline Tobacco exposure & $17(81 \%)$ & $31(79 \%)$ & \\
\hline No tobacco exposure & $4(19 \%)$ & $8(21 \%)$ & \\
\hline \multicolumn{3}{|l|}{ Alcohol use, $n(\%)$} & \multirow[t]{3}{*}{0.911} \\
\hline Alcohol exposure & $14(67 \%)$ & $24(62 \%)$ & \\
\hline No alcohol exposure & $7(33 \%)$ & $15(38 \%)$ & \\
\hline \multicolumn{3}{|l|}{$\mathrm{T}$ classification, $n(\%)$} & \multirow[t]{3}{*}{0.294} \\
\hline $\mathrm{T} 1-\mathrm{T} 2$ & $6(29 \%)$ & $18(46 \%)$ & \\
\hline $\mathrm{T} 3-\mathrm{T} 4$ & $15(71 \%)$ & $21(54 \%)$ & \\
\hline \multicolumn{3}{|l|}{$\mathrm{N}$ classification, $n(\%)$} & \multirow[t]{3}{*}{0.743} \\
\hline NO & $8(38 \%)$ & $18(46 \%)$ & \\
\hline $\mathrm{N}+$ & $13(62 \%)$ & $21(54 \%)$ & \\
\hline \multicolumn{3}{|l|}{ M classification, $n(\%)$} & \multirow[t]{3}{*}{ NA } \\
\hline M0 & $21(100 \%)$ & $39(100 \%)$ & \\
\hline $\mathrm{M}+$ & $0(0 \%)$ & $0(0 \%)$ & \\
\hline \multicolumn{3}{|l|}{ Clinical stage, $n(\%)$} & \multirow[t]{3}{*}{0.340} \\
\hline I-II & $3(14 \%)$ & $11(28 \%)$ & \\
\hline III-IV & $18(86 \%)$ & $28(72 \%)$ & \\
\hline \multicolumn{3}{|l|}{ Histological grade, $n(\%)$} & \multirow[t]{4}{*}{$0.042^{\mathrm{a}}$} \\
\hline Well-differentiated & $13(62 \%)$ & $23(59 \%)$ & \\
\hline Moderately differentiated & $3(14 \%)$ & $14(36 \%)$ & \\
\hline Poorly differentiated & $5(24 \%)$ & $2(5 \%)$ & \\
\hline \multicolumn{3}{|l|}{ Treatment, $n(\%)$} & \multirow[t]{5}{*}{$0.731^{\mathrm{a}}$} \\
\hline Surgery & $8(38 \%)$ & $19(49 \%)$ & \\
\hline RT & $1(5 \%)$ & $3(8 \%)$ & \\
\hline Surgery + RT & $11(52 \%)$ & $16(41 \%)$ & \\
\hline Surgery $+\mathrm{RT}+\mathrm{ChT}$ & $1(5 \%)$ & $1(2 \%)$ & \\
\hline
\end{tabular}

NA, not applicable; RT, radiotherapy; ChT, chemotherapy.

${ }^{a}$ Fisher's exact test.

difference between the groups $(P=0.493)$ (Table 4). There was a tendency towards an association between gene amplification and EGFR overexpression; however this was not statistically significant $(P=0.138)$, probably due to the low number of cases of gene amplification.

Analysis of the association between the clinicopathological data and FISH results showed that EGFR amplification was significantly more prevalent in advanced tumours $(P=0.013)$, regardless of age (Table 5). The mean duration of followup was 40.7 months (range 1 to 136 months), and the mean time to recurrence was 14 months in the test group and 27 months in the control group, but the difference between groups was not statistically significant $(P=0.248)$.

The impact of EGFR overexpression on disease progression and survival in all of the patients was determined by Cox proportional hazards regression analysis (Table 6). Multivariate analysis revealed a 5.0-fold increased risk of death from disease in all patients who had membrane EGFR overexpression.

No statistically significant association was observed between $E G F R$ amplification and survival rates $(P>0.05)$. Kaplan-Meier survival curves for patients who had membrane EGFR overexpression are shown in Fig. $2(P<0.05)$.

\section{Discussion}

OSCC is uncommon in young adults $(\leq 40$ years old $)^{26}$. Some authors have suggested that the disease has a more aggressive course in this age group $3,27,28$, but no consensus exists ${ }^{19,29-33}$. Studies have shown an increase in the number of OSCC cases among young female patients ${ }^{3-5}$, while the present study found a higher incidence in males, Caucasians, smokers, and alcohol drinkers. Despite the high incidence of OSCC among smokers and drinkers, there are no relationships between EGFR expression or amplification and alcohol and tobacco use $\mathrm{e}^{14,34,35}$, as observed in this study.

There are no studies in the English language literature investigating $E G F R$ amplification specifically in young adults. In the present study, amplification was higher in the test group $(\leq 40$ years old) than in control patients. In a previous study of patients with colorectal cancer, Cappuzzo et al. suggested that patients with a high EGFR gene copy number have an increased likelihood of responding to monoclonal antibody therapy $^{36}$. 
Table 2. Cox proportional hazards regression analysis for all patients, related to clinical characteristics.

\begin{tabular}{|c|c|c|c|c|c|c|c|c|c|}
\hline \multirow{2}{*}{ Variable } & \multicolumn{3}{|c|}{ Overall survival } & \multicolumn{3}{|c|}{ Disease-free survival } & \multicolumn{3}{|c|}{ Disease-specific survival } \\
\hline & HR & $95 \% \mathrm{CI}$ & $P$-value & HR & $95 \% \mathrm{CI}$ & $P$-value & HR & $95 \%$ CI & $P$-value \\
\hline \multicolumn{10}{|l|}{$\mathrm{T}$ classification } \\
\hline $\begin{array}{l}\text { T3-T4 } \\
\text { Univariate model }\end{array}$ & 6.14 & $2.52-14.99$ & $<0.001$ & 2.18 & $1.01-4.71$ & 0.048 & 7.20 & $2.45-21.17$ & $<0.001$ \\
\hline $\begin{array}{l}\text { T3-T4 } \\
\text { Multivariate model }\end{array}$ & 5.87 & $2.17-15.89$ & $<0.001$ & 1.88 & $0.86-4.10$ & 0.112 & 6.52 & $1.84-23.15$ & 0.004 \\
\hline \multicolumn{10}{|l|}{ Margins } \\
\hline $\begin{array}{l}\text { Positive } \\
\text { Univariate model }\end{array}$ & 6.93 & $1.77-27.12$ & 0.005 & 5.51 & $1.52-20.00$ & 0.009 & 10.43 & $2.46-44.34$ & 0.001 \\
\hline $\begin{array}{l}\text { Positive } \\
\text { Multivariate model }\end{array}$ & 4.03 & $1.03-15.89$ & 0.046 & 5.89 & $1.57-22.18$ & 0.009 & 5.94 & $1.39-25.49$ & 0.016 \\
\hline
\end{tabular}

HR, hazard ratio (estimated from the Cox proportional hazards regression model); CI, confidence interval of the estimated HR.

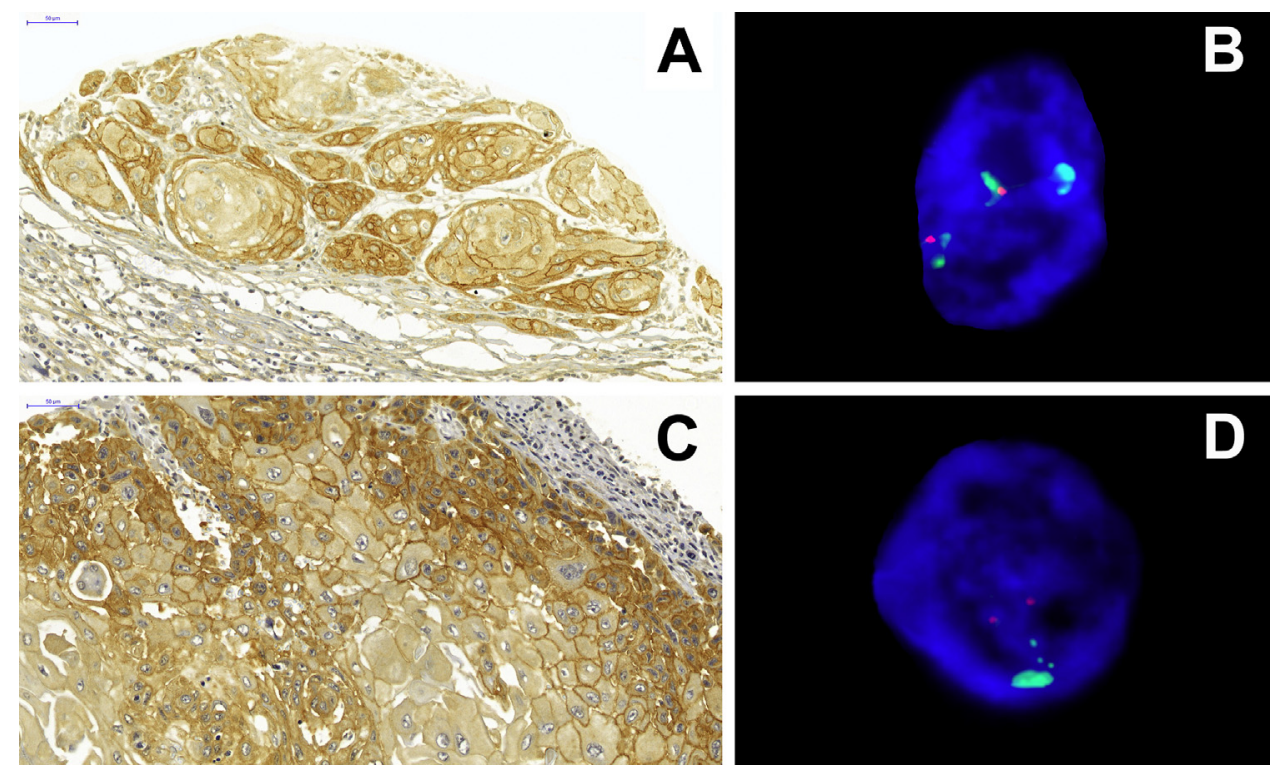

Fig. 1. EGFR protein expression and EGFR gene amplification in OSCC. (A) Membrane overexpression in OSCC cells of the test group; (B) $E G F R$ amplification in the test group; (C) membrane overexpression in OSCC cells of the control group; (D) EGFR amplification in the control group. Immunohistochemistry: Mayer's haematoxylin counterstain. FISH: DAPI stain, CEN7 (red) and EGFR (green) probes.

Significant association between gene amplification and clinicopathological data is not a common finding ${ }^{14,37,38}$. However, Huang et al. reported that EGFR gene amplification was significantly more prevalent in advanced tumours ${ }^{13}$, as also demonstrated in this study. The present study findings showed this gene to be more

amplified in the younger age group; however, the mechanism by which EGFR FISH status contributes to the oncogenic effect in expressing cells remains unclear $^{39}$.

Although no association between EGFR expression and clinicopathological data was observed in this study, Xia et al. found

Table 3. EGFR FISH results for young adults and controls.

\begin{tabular}{llll}
\hline Group & No $E G F R$ amplification & $E G F R$ amplification & $P$-value \\
\hline Test, $n(\%)$ & $15(71.4 \%)$ & $6(28.6 \%)$ & 0.018 \\
Control, $n(\%)$ & $37(94.9 \%)$ & $2(5.1 \%)$ & \\
\hline
\end{tabular}

EGFR, epidermal growth factor receptor; FISH, fluorescence in situ hybridization.

Table 4. EGFR immunostaining results for young adults and controls.

\begin{tabular}{llll}
\hline Group & EGFR underexpression & EGFR overexpression & $P$-value \\
\hline Test, $n(\%)$ & $7(33.3 \%)$ & $14(66.7 \%)$ & 0.493 \\
Control, $n(\%)$ & $18(46.2 \%)$ & $21(53.8 \%)$ & \\
\hline
\end{tabular}

EGFR, epidermal growth factor receptor. a significant association between EGFR expression levels and metastasis ${ }^{11}$. This could be explained by the role of EGFR in oncogenesis, in which mutations in this gene can activate multiple pathways, such as Ras/Raf/MEK/ERK and Ras/PI3K/ $\mathrm{PTEN} / \mathrm{Akt} / \mathrm{mTOR}^{40}$. The activation of these pathways can induce numerous cellular processes, including differentiation, transformation, proliferation, invasion, migration, angiogenesis, and inhibition of apoptosis ${ }^{8,15}$, and this could also explain the poor outcomes of patients with EGFR overexpression, which occurs mainly in advanced tumours. Moreover, abnormal activation of EGFR signalling in head and neck squamous cell carcinoma may be accomplished by different mechanisms, including overexpression of EGFR and its ligands, the establishment of autocrine/paracrine loops, EGFR mutation or polymorphism, EGFR amplification, and 
Table 5. EGFR FISH results versus clinicopathological features in all patients, regardless of age.

\begin{tabular}{lllll}
\hline & & \multicolumn{2}{c}{$E G F R$} & \multirow{2}{*}{$P$-value } \\
\cline { 3 - 4 } & & No amplification & Amplification & \\
\hline T classification & T1-T2 & $23(44.2 \%)$ & $1(12.5 \%)$ & 0.128 \\
& T3-T4 & $29(55.8 \%)$ & $7(87.5 \%)$ & \multirow{2}{*}{ N classification } \\
& N0 & $24(46.2 \%)$ & $2(25 \%)$ & 0.446 \\
& N+ & $28(53.8 \%)$ & $6(75 \%)$ & \multirow{2}{*}{ NA } \\
M classification & M0 & $52(100 \%)$ & $8(100 \%)$ & \multirow{2}{*}{ Clinical stage } \\
& M+ & $0(0 \%)$ & $0(0 \%)$ & 0.013 \\
& I-II & $13(25 \%)$ & $1(12.5 \%)$ & \\
\hline
\end{tabular}

EGFR, epidermal growth factor receptor; FISH, fluorescence in situ hybridization; NA, not applicable.

Table 6. EGFR expression: multivariate Cox proportional hazards regression analysis for all patients.

\begin{tabular}{lllll}
\hline Variable & Cut-off expression & HR & $95 \%$ CI & $P$-value \\
\hline Overall survival & EGFR $>72$ & 3.8 & $1.17-12.48$ & 0.027 \\
Disease-free survival & EGFR $>76$ & 2.6 & $1.16-5.91$ & 0.021 \\
Disease-specific survival & EGFR $>73$ & 5.0 & $1.18-21.2$ & 0.028 \\
\hline
\end{tabular}

EGFR, epidermal growth factor receptor; HR, hazard ratio (estimated from the Cox proportional hazards regression model); CI, confidence interval of the estimated HR.

transactivation by other tyrosine kinase receptors $^{39}$.

Interestingly, in addition to membrane staining, some of the present cases exhibited cytoplasmic EGFR staining. Cytoplasmic EGFR staining may indicate the translocation of EGFR from the membrane to the cytoplasm during cell-stromal interactions, leading to cytoplasmic EGFR overexpression and a more aggressive tumour behaviour ${ }^{41}$. Other authors have hypothesized that a rise in the $150-\mathrm{kDa}$ form of EGFR is due to increased degradation of the mature $170-\mathrm{kDa}$ form of the receptor through saturation of the degradation mechanism in the lysosomal compartment, resulting in cytoplasmic EGFR ac- cumulation $^{42}$. Chiang et al. reported nuclear or nuclear and cytoplasmic EGFR expression in $67 \%$ of OSCC samples ${ }^{43}$. The presence of nuclear staining is a common finding and is related to resistance to radiotherapy ${ }^{44}$. However, nuclear staining was not observed in any of the present cases.

In this study, there was a tendency towards an association between gene amplification and EGFR overexpression; however it was not statistically significant. A post-translational mechanism could be involved in this imbalance. For example, ring finger protein RNF11 overexpression is sufficient to increase the expression of EGFR and is accompanied by RNF11- dependent up-regulation of the inner coat protein complex II (COPII) paralogues SEC2B, SEC24B, and SEC24D, which are required for EGFR degradation and transport to the plasma membrane ${ }^{45}$. In addition, cylindromatosis tumour suppressor protein (CYLD) facilitates the interaction of EGFR with CBL-B through its Tyr15 phosphorylation in response to epidermal growth factor, which leads to EGFR ubiquitination and subsequent degradation $^{46}$.

Szabó et al. associated the relationship between EGFR overexpression and gene amplification with a poor outcome ${ }^{34}$. However, some authors have only found a poor outcome in association with $E G F R$ amplification $^{37,47}$. In the present study, OSCC survival was significantly influenced by the level of EGFR expression, similar to the findings of other studies ${ }^{13,34}$. No association was observed between $E G F R$ amplification and survival rates, which is in accordance with earlier find$\operatorname{ings}^{13,35,38}$.

In summary, despite the higher amplification of EGFR in young adults, it was found not to significantly impact the survival rates of affected patients. Tumours with positive margins, a larger size, and higher EGFR expression were found to have a negative impact on disease progression and survival rates. Furthermore, patients with OSCC who show membranous EGFR overexpression could possibly benefit from anti-EGFR immunotherapy, regardless of their age.

\section{Funding}

This study was supported by FAPEAM (grant number 254/2014) and FAPESP (grant number 12/21660-6).
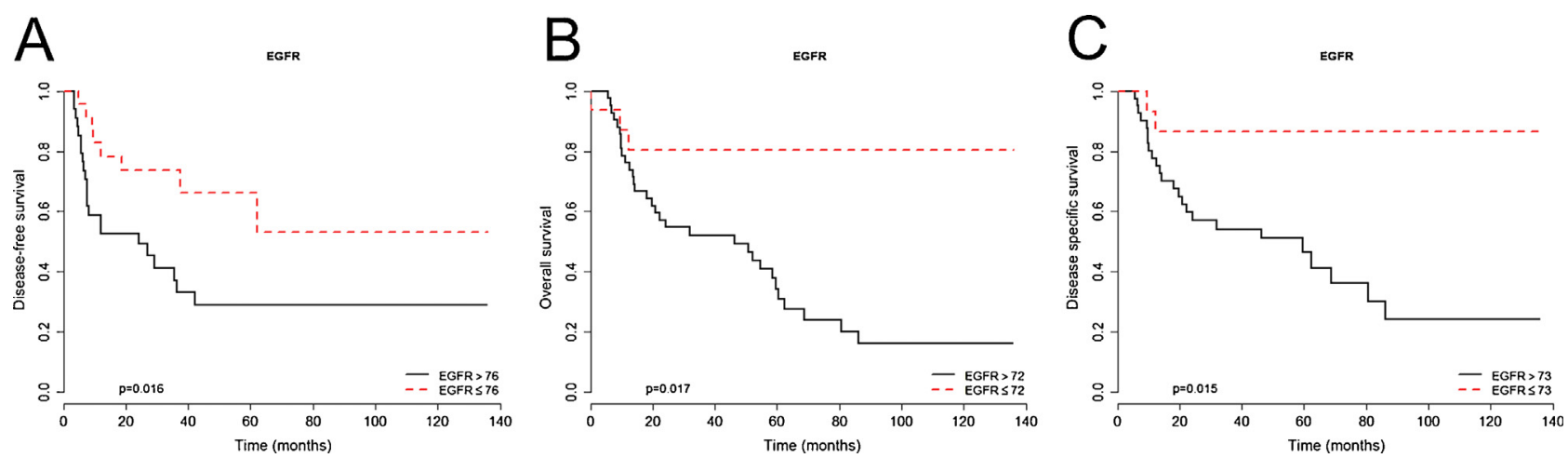

Fig. 2. Kaplan-Meier survival curves for patients with EGFR overexpression, regardless of age. (A) Disease-free survival $(P=0.016)$; (B) overall survival $(P=0.017)$; $(C)$ disease-specific survival $(P=0.015)$. The effect of EGFR overexpression was significant in all the survival curves. 


\section{Competing interests}

None.

\section{Ethical approval}

The Ethics Committee of the Institute of Science and Technology, Unesp approved the study under protocol number 1.227.336.

\section{Patient consent}

Not required.

Acknowledgements. The authors would like to thank to FAPEAM for granting a Master's fellowship to V. Costa (grant number 254/2014) and FAPESP (grant number 12/21660-6) for financial support.

\section{References}

1. Barnes L, Eveson JW, Reichart P, Sidransky D. Pathology and genetics of head and neck tumours. WHO classification of tumours. Lyon: IARC Press; 2005: 163-75.

2. Cancer Research UK. Oral cancer statistics 2016. http://www.cancerresearchuk.org/ health-professional/cancer-statistics/ statistics-by-cancer-type/oral-cancer/ incidence2016 [Accessibility verified July 30, 2017].

3. Kuriakose M, Sankaranarayanan M, Nair MK, Cherian T, Sugar AW, Scully C, Prime SS. Comparison of oral squamous cell carcinoma in younger and older patients in India. Eur J Cancer Part B Oral Oncol 1992;28:113-20. http://dx.doi.org/10.1016/ 0964-1955(92)90038-3.

4. Chitapanarux I, Lorvidhaya V, Sittitrai P, Pattarasakulchai T, Tharavichitkul E, Sriuthaisiriwong P, Kamnerdsupaphon P, Sukthomya V. Oral cavity cancers at a young age: analysis of patient, tumor and treatment characteristics in Chiang Mai University Hospital. Oral Oncol 2006;42:83-8. http:// dx.doi.org/10.1016/j.oraloncology.2005.06.015.

5. Patel SC, Carpenter WR, Tyree S, Couch ME, Weissler M, Hackman T, Hayes DN, Shores C, Chera BS. Increasing incidence of oral tongue squamous cell carcinoma in young white women, age 18 to 44 years. $J$ Clin Oncol 2011;29:1488-94. http://dx.doi. org/10.1200/JCO.2010.31.7883.

6. Soudry E, Preis M, Hod R, Hamzany Y, Hadar T, Bahar G, Strenov Y, Shpitzer T. Squamous cell carcinoma of the oral tongue in patients younger than 30 years: clinicopathologic features and outcome. Clin Otolaryngol 2010;35:307-12. http://dx.doi.org/ 10.1111/j.1749-4486.2010.02164.x.

7. Kaminagakura E, Werneck da Cunha I, Soares FA, Nishimoto IN, Kowalski LP.
CCND1 amplification and protein overexpression in oral squamous cell carcinoma of young patients. Head Neck 2011;33:1413-9. http://dx.doi.org/10.1002/hed.21618.

8. Cappuzzo F, Hirsch FR, Rossi E, Bartolini S, Ceresoli GL, Bemis L, Haney J, Witta S, Danenberg K, Domenichini I, Ludovini V, Magrini E, Gregorc V, Doglioni C, Sidoni A, Tonato M, Franklin WA, Crino L, Bunn Jr PA, Varella-Garcia M. Epidermal growth factor receptor gene and protein and gefitinib sensitivity in non-small-cell lung cancer. $J$ Natl Cancer Inst 2005;97:643-55. http://dx. doi.org/10.1093/jnci/dji112.

9. Coussens L, Yang-Feng TL, Liao YC, Chen E, Gray a. McGrath J, Seeburg PH, Libermann TA, Schlessinger J, Francke U, Levinson A, Ullrich A. Tyrosine kinase receptor with extensive homology to EGF receptor shares chromosomal location with neu oncogene. Science 1985;230(4730):1132-9. http://dx.doi.org/10.1126/science.2999974.

10. Gullick WJ, Downward J, Parker PJ, Whittle N, Kris R, Schlessinger J, Ullrich A, Waterfield MD. The structure and function of the epidermal growth factor receptor studied by using antisynthetic peptide antibodies. Proc R Soc Lond B Biol Sci 1985;226:127-34.

11. Xia W, Lau YK, Zhang HZ, Xiao FY, Johnston DA, Liu AR, Li L, Katz RL, Hung MC. Combination of EGFR, HER-2/neu, and HER-3 is a stronger predictor for the outcome of oral squamous cell carcinoma than any individual family members. Clin Cancer Res 1999;5:4164-74.

12. Subramaniam D, He AR, Hwang J, Deeken J, Pishvaian M, Hartley ML, Marshall JL. Irreversible multitargeted ErbB family inhibitors for therapy of lung and breast cancer. Curr Cancer Drug Targets 2015;14:775-93.

13. Huang SF, Cheng SD, Chien HT, Liao CT, Chen IH, Wang HM, Chuang WY, Wang CY, Hsieh LL. Relationship between epidermal growth factor receptor gene copy number and protein expression in oral cavity squamous cell carcinoma. Oral Oncol 2012;48:67-72. http://dx.doi.org/10.1016/j. oraloncology.2011.06.511.

14. Bernardes VF, Gleber-Netto FO, de Sousa SF, Rocha RM, de Aguiar MC. EGFR status in oral squamous cell carcinoma: comparing immunohistochemistry, FISH and CISH detection in a case series study. BMJ Open 2013;3:e002077. http://dx.doi.org/10.1136/ bmjopen-2012-002077.

15. Cuneo KC, Nyati MK, Ray D, Lawrence TS. EGFR targeted therapies and radiation: optimizing efficacy by appropriate drug scheduling and patient selection. Pharmacol Ther 2015;154:67-77. http://dx.doi.org/10.1016/ j.pharmthera.2015.07.002.

16. van der Linden N, van Gils CW, Pescott CP, Buter J, Vergeer MR, Groot CA. Real-world cost-effectiveness of cetuximab in locally advanced squamous cell carcinoma of the head and neck. Eur Arch Otorhinolaryngol
2015;272:2007-16. http://dx.doi.org/ 10.1007/s00405-014-3106-3.

17. Miranda Galvis M, Santos-Silva AR, Jardim JF, Fonseca FP, Lopes MA, Almeida OP, Lópes Pinto CA, Kaminagakura E, Sawazaki-Calone I, Speight PM, Kowalski LP. Different patterns of expression of cell cycle control and local invasion-related proteins in oral squamous cell carcinoma affecting young patients. J Oral Pathol Med 2017. http://dx.doi.org/10.1111/iop.12601. [Epub ahead of print].

18. Greene FL, Page DL, Fleming ID, Fritz AG, Balch CM, Haller DG, Morrow M. American Joint Committee on Cancer. AJCC cancer staging manual. New York: Springer; 2002.

19. Kaminagakura E, Vartanian JG, da Silva SD, dos Santos CR, Kowalski LP. Case-control study on prognostic factors in oral squamous cell carcinoma in young patients. Head Neck 2010;32:1460-6. http://dx.doi.org/10.1002/ hed.21347.

20. Jiang H, Bai X, Meng F, Zhang C, Zhang X. Evaluation of chromosome 17 polysomy in breast cancer by FISH analysis of whole nuclei, and its clinicopathological significance. Oncol Lett 2014;7:1954-8. http:// dx.doi.org/10.3892/ol.2014.2001.

21. Fukazawa EM, Baiocchi G, Soares FA, Kumagai LY, Faloppa CC, Badiglian-Filho L, Coelho FR, Gonçalves WJ, Costa RL, Góes JC. Cox-2, EGFR, and ERBB-2 expression in cervical intraepithelial neoplasia and cervical cancer using an automated imaging system. Int $J$ Gynecol Pathol 2014;33:225-34. http://dx.doi.org/10.1097/ PGP.0b013e318290405a.

22. Lausen B, Schumacher M. Maximally selected rank statistics. Biometrics 1992;48:73. http://dx.doi.org/10.2307/2532740.

23. Cox DR. Regression models and life-tables. J R Stat Soc Ser B 1972;34:187-220. http:// dx.doi.org/10.2307/2985181

24. Schoenfeld D. Partial residuals for the proportional hazards regression model. Biometrika 1982;69:239. http://dx.doi.org/ 10.2307/2335876.

25. Grambsch PM, Therneau TM. Proportional hazards tests and diagnostics based on weighted residuals. Biometrika 1994;81:515. http://dx.doi.org/10.2307/ 2337123.

26. Kaminagakura E, Villa LL, Andreoli MA, Sobrinho JS, Vartanian JG, Soares FA, Nishimoto IN, Rocha R, Kowalski LP. High-risk human papillomavirus in oral squamous cell carcinoma of young patients. Int $J$ Cancer 2012;130:1726-32. http://dx.doi.org/ 10.1002/ijc.26185.

27. Popovtzer A, Shpitzer T, Bahar G, Marshak G, Ulanovski D, Feinmesser R. Squamous cell carcinoma of the oral tongue in young patients. Laryngoscope 2004;114:915-7. http://dx.doi.org/10.1097/00005537200405000-00025.

28. Zhang YY, Wang DC, Su JZ, Jia LF, Peng X, Yu GY. Clinicopathological characteristics 
and outcomes of squamous cell carcinoma of the tongue in different age groups. Head Neck 2017;39:2276-82. http://dx.doi.org/ 10.1002/hed.24898.

29. Myers JN, Elkins T, Roberts D, Byers RM. Squamous cell carcinoma of the tongue in young adults: increasing incidence and factors that predict treatment outcomes. Otolaryngol Head Neck Surg 2000;122:44-51.

30. Hyam DM, Conway RC, Sathiyaseelan Y, Gebski V, Morgan GJ, Walker DM, Veness MJ. Tongue cancer: do patients younger than 40 do worse? Aust Dent J 2003;48:50-4. http://dx.doi.org/10.1111/j.1834-7819.2003. tb00009.x.

31. Manuel S, Raghavan SK, Pandey M, Sebastian P. Survival in patients under 45 years with squamous cell carcinoma of the oral tongue. Int $J$ Oral Maxillofac Surg 2003;32:167-73. http://dx.doi.org/10.1054/ ijom.2002.0271.

32. Sasaki T, Moles DR, Imai Y, Speight PM. Clinico-pathological features of squamous cell carcinoma of the oral cavity in patients $<40$ years of age. J Oral Pathol Med 2005;34:129-33. http://dx.doi.org/10.1111/ j.1600-0714.2004.00291.x.

33. de Morais EF, Mafra RP, Gonzaga AK, de Souza DL, Pinto LP, da Silveira EJ. Prognostic factors of oral squamous cell carcinoma in young patients: a systematic review. $J$ Oral Maxillofac Surg 2017;75:1555-66. http://dx.doi.org/10.1016/i. joms.2016.12.017.

34. Szabó B, Nelhubel GA, Kárpáti A, Kenessey I, Jóri B, Székely C, Peták I, Lotz G, Hegedus Z, Hegedus B, Füle T, Döme B, Tímár J, Tóvári J. Clinical significance of genetic alterations and expression of epidermal growth factor receptor (EGFR) in head and neck squamous cell carcinomas. Oral Oncol 2011;47:487-96. http://dx.doi.org/10.1016/ j.oraloncology.2011.03.020.

35. Wangsa D, Chowdhury SA, Ryott M, Gertz EM, Elmberger G, Auer G, Åvall Lundqvist E, Küffer S, Ströbel $P$, Schäffer AA, Schwartz R, Munck-Wikland E, Ried T, Heselmeyer-Haddad K. Phylogenetic analysis of multiple FISH markers in oral tongue squamous cell carcinoma suggests that a diverse distribution of copy number changes is associated with poor prognosis. Int J Cancer 2016;138:98-109. http://dx.doi.org/ 10.1002/ijc.29691.
36. Cappuzzo F, Finocchiaro G, Rossi E, Jänne PA, Carnaghi C, Calandri C, Bencardino K, Ligorio C, Ciardiello F, Pressiani T, Destro A, Roncalli M, Crino L, Franklin WA, Santoro A, Varella-Garcia M. EGFR FISH assay predicts for response to cetuximab in chemotherapy refractory colorectal cancer patients. Ann Oncol 2008;19:717-23. http://dx.doi.org/10.1093/annonc/mdm492.

37. Nakata Y, Uzawa N, Takahashi K-I, Sumino J, Michikawa C, Sato H, Sonoda I, Ohyama Y, Okada N, Amagasa T. EGFR gene copy number alteration is a better prognostic indicator than protein overexpression in oral tongue squamous cell carcinomas. Eur $J$ Cancer 2011;47:2364-72. http://dx.doi.org/ 10.1016/j.ejca.2011.07.006.

38. Gröbe A, Eichhorn W, Fraederich M, Kluwe L, Vashist Y, Wikner J, Smeets R, Simon R, Sauter G, Heiland M, Blessmann M. Immunohistochemical and FISH analysis of EGFR and its prognostic value in patients with oral squamous cell carcinoma. J Oral Pathol Med 2014;43:205-10. http://dx.doi.org/10.1111/ jop.12111.

39. Bossi P, Resteghini C, Paielli N, Licitra L, Pilotti S, Perrone F. Prognostic and predictive value of EGFR in head and neck squamous cell carcinoma 2016:1-40. doi: 10.18632/oncotarget.11413.

40. Steelman LS, Chappell WH, Abrams SL, Kempf CR, Long J, Laidler P, Mijatovic S, Maksimovic-Ivanic D, Stivala F, Mazzarino MC, Donia M, Fagone P, Malaponte G, Nicoletti F, Libra M, Milella M, Tafuri A, Bonati A, Bäsecke J, Cocco L, Evangelisti C, Martelli AM, Montalto G, Cervello M, McCubrey JA. Roles of the Raf/MEK/ ERK and PI3 K/PTEN/Akt/mTOR pathways in controlling growth and sensitivity to therapy-implications for cancer and aging. $A g$ ing (Albany NY) 2011;3:192-222. http://dx. doi.org/10.18632/aging.100296. [pii].

41. Braut T, Krstulja M, Rukavina KM, Jonjić N, Kujundić M, Manestar ID, Katunarić M, Manestar D. Cytoplasmic EGFR staining and gene amplification in glottic cancer. Appl Immunohistochem Mol Morphol 2014;22:674-80. http://dx.doi.org/10.1097/ PAI.0000000000000014.

42. Ueda S, Tsuda H, Kawarabayashi N, Kimura M, Sugiura Y, Tamai S, Matsubara O, Hatsuse K, Mochizuki HS. The correlation between cytoplasmic overexpression of epidermal growth factor receptor and tumor aggressiveness: poor prognosis in patients with pancreatic ductal adenocarcinoma. Pancreas 2004;29:e1-8. doi:00006676200407000-00061 [pii].

43. Chiang WF, Liu SY, Yen CY, Lin CN, Chen YC, Lin SC, Chang KW. Association of epidermal growth factor receptor (EGFR) gene copy number amplification with neck lymph node metastasis in areca-associated oral carcinomas. Oral Oncol 2008;44:270-6. http://dx.doi.org/10.1016/j.oraloncology.2007.02.008.

44. Chen DJ, Nirodi CS. The epidermal growth factor receptor: a role in repair of radiationinduced DNA damage. Clin Cancer Res 2007;13:6555-60. http://dx.doi.org/ 10.1158/1078-0432.CCR-07-1610.

45. Scharaw S, Iskar M, Ori A, Boncompain G, Laketa V, Poser I, Lundberg E, Perez F, Beck M, Bork P, Pepperkok R. The endosomal transcriptional regulator RNF11 integrates degradation and transport of EGFR. $J$ Cell Biol 2016;215:543-58. http://dx.doi.org/ 10.1083/jcb.201601090.

46. Sanchez-Quiles V, Akimov V, Osinalde N, Francavilla C, Puglia M, Barrio-Hernandez I, Kratchmarova I, Olsen JV, Blagoev B. CYLD deubiquitinase is necessary for proper ubiquitination and degradation of the epidermal growth factor receptor. Mol Cell Proteomics 2017;16:1433-46. http://dx.doi. org/10.1074/mcp.M116.066423.

47. Temam S, Kawaguchi H, El-Naggar AK, Jelinek J, Tang H, Liu DD, Lang W, Issa JP, Lee JJ, Mao L. Epidermal growth factor receptor copy number alterations correlate with poor clinical outcome in patients with head and neck squamous cancer. $J$ Clin Oncol 2007;25:2164-70. http://dx.doi.org/ $\underline{10.1200 / \mathrm{JCO} .2006 .06 .6605}$.

Address:

Estela Kaminagakura

Department of Bioscience and Oral Diagnosis Institute of Science and Technology Universidade Estadual Paulista

Av. Eng. Francisco José Longo 777

São José dos Campos 12245-000

Brazil

Tel.: +551239479401

Fax: +551239479010

E-mail: estela@fosjc.unesp.br 